\title{
Organic matter input and processing in two contrasting North Sea sediments: insights from stable isotope and biomass data
}

\author{
Dick van Oevelen ${ }^{1, *}$, Karline Soetaert ${ }^{1}$, Maria A. Franco ${ }^{2,3}$, Leon Moodley ${ }^{1}$, \\ Lennart van IJzerloo ${ }^{1}$, Magda Vincx ${ }^{2}$, Jan Vanaverbeke ${ }^{2}$ \\ ${ }^{1}$ Centre for Estuarine and Marine Ecology, Netherlands Institute of Ecology (NIOO-KNAW), PO Box 140, 4400 AC Yerseke, \\ The Netherlands \\ ${ }^{2}$ Marine Biology Section, Biology Department, Ghent University, Krijgslaan 281 (S8), 9000 Gent, Belgium \\ ${ }^{3}$ Instituto de Oceanografia, Faculty of Sciences, University of Lisbon, Campo Grande, 1749-016 Lisboa, Portugal
}

\begin{abstract}
Organic matter input and processing was studied in 2 contrasting sediments (Stn 115 and Stn $\left.330_{\text {COAREE }}\right)$ in the southern North Sea. The sediments are subjected to similar hydrodynamic conditions, but Stn $115_{\mathrm{FINE}}$ underlies a high turbidity zone, making it a fine, low-permeability sediment. Monthly data on chlorophyll a ( $\mathrm{chl} a), \delta^{13} \mathrm{C}$ and $\delta^{15} \mathrm{~N}$ of particulate organic matter in the water column and sediment showed that the algal spring bloom deposition created a strong vertical gradient of sedimentary chl $a$ at Stn $115_{\mathrm{FINE}}$. Macrobenthic biomass $\left(78 \pm 60 \mathrm{~g} \mathrm{C} \mathrm{m}^{-2}\right.$, mean $\pm \mathrm{SD}$ ) was dominated by suspension feeders, suggesting biological mediation of the organic matter input. In contrast, the offshore Stn $330_{\text {COARSE }}$ is a coarse, high-permeability sediment in which chl a penetrated centimeters deep due to physically mediated input. The macrobenthic community, low in biomass $\left(3.8 \pm 2.4 \mathrm{~g} \mathrm{C} \mathrm{m}^{-2}\right)$, was dominated by mobile polychaetes and epibenthic amphipods, which is characteristic of physically disturbed sediments. Overall, sediment characteristics played an important but indirect role in the organic matter input and processing. At Stn $115_{\mathrm{FINE}}$ a large macrobenthic community developed that mediated the input of organic matter to the sediment through herbivore and predatory pathways. At Stn $330_{\text {COARSE }}$ in contrast, organic matter input seemed to be dominated by physical processes. Overall, the fraction of algal carbon degraded in the sediment was higher at Stn $115_{\text {FINE }}$ than at Stn $330_{\text {COARSE }}$ indicating that the physical input at Stn $330_{\text {COAREE }}$ was less efficient than the biological input at Stn $115_{\mathrm{FINE}}$.
\end{abstract}

KEY WORDS: Food web · Carbon isotope $\cdot$ Nitrogen isotope $\cdot$ Coastal sediment $\cdot$ North sea $\cdot$ Permeable sediment $\cdot$ Benthic $\cdot$ Pelagic coupling

Resale or republication not permitted without written consent of the publisher

\section{INTRODUCTION}

Coarse sediments typically have low organic matter content and were therefore long considered to be unimportant in terms of organic matter mineralization as compared to muddy sediments. This view has changed drastically in the last decade. Coarse sediments underlie dynamic shelf seas, in which hydrodynamic forces have a sorting effect on the sediment particles during resuspension, and create ripples and other topographic bed features. Recurrent resuspension and pressure differences from wave action and topographic bed features result in an advective 'injection' of fresh organic matter and oxygen into permeable coarse sediments (Huettel et al. 1996). These advective inputs result in high rates of organic matter turnover in permeable coarse sediments (Huettel \& Rusch 2000) that can be comparable to muddy sediments (D'Andrea et al. 2002). In contrast, finer sediments typically accumulate in regions of lower hydrodynamic stress, and organic matter settles passively on the sediment surface and is then subjected to (bio)diffusive mixing into the sediment.

In addition to the physically mediated inputs of organic matter to sediments (advective injection and 
passive deposition), there is biologically mediated input, in which benthic organisms actively filter and deposit organic matter from the water column on and into surface sediments (Kautsky \& Evans 1987, Chiantore et al. 1998). The scope for biologically mediated input of organic matter is, however, related to the physical environment, because coarse sediments are frequently subjected to resuspension and mobilization events, which may prevent the establishment of an infaunal benthic community (Ysebaert et al. 2000, Aller \& Aller 2004, Wlodarska-Kowalczuk et al. 2007). As a result of such sediment mobilizing events, organic matter degradation in deltaic sediments is dominated by bacteria due to the high disturbance regime of these sediments (Aller \& Aller 2004).

The input of organic matter depends strongly on the physical setting and typical co-varying factors such as sediment type and disturbance regime. We investigated organic matter input at 2 contrasting sediments on the Belgian Continental Shelf (BCS). The BCS is situated in the Southern Bight of the North Sea and is a complex system of beaches, gullies and sandbanks that are characterized by different sediment types ranging from clays to coarse sands (Fettweis \& Van den Eynde 2003, Van Hoey et al. 2004). The BCS receives high nutrient inputs from the rivers Rhine, Meuse and Scheldt that give rise to pronounced spring blooms of diatoms and Phaeocystis, reaching con-

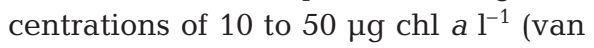
der Zee \& Chou 2005) and an annual net primary production of 134 to $213 \mathrm{~g}$ $\mathrm{C} \mathrm{m}^{-2}$ (Lancelot et al. 2005).

The sediments of the BCS are interesting sites to follow the input and fate of organic matter, because hydrodynamic conditions such as current velocity (1 to $2 \mathrm{~m} \mathrm{~s}^{-1}$ ) and bottom shear stress $(0.8$ to $1.5 \mathrm{~Pa})$ suggest comparable hydrodynamic conditions on the BCS (Fettweis \& Van den Eynde 2003). An important factor governing differences in sediment type is the presence of a high turbidity zone in front of the coast, resulting in coarser offshore sediments and finer coastal sediments (Fettweis \& Van den Eynde 2003). Hence, whereas coastal and offshore sediments are subjected to similar physical forces, coastal sediments are more stable and less permeable due to the input of fine particles from the water column (see 'Study site and cruises' in 'Materials and methods').

We selected a fine coastal sediment (Stn $115_{\text {FINE }}$ ) and a coarse offshore sedi- ment (Stn 330 COARSE$_{\text {) }}$ and assessed the input to and degradation of particulate organic matter (POM) through different variables. (1) The dynamics of chlorophyll a $(\mathrm{chl}$ a) in the water column and sediment were taken as a direct measure of phytoplankton deposition and subsequent degradation in the sediment (Sun et al. 1991). (2) $\delta^{13} \mathrm{C}$ and $\delta^{15} \mathrm{~N}$ isotope values of water column POM (wPOM) and sedimentary POM (sPOM) were measured, because substrate depletion during an algal bloom may lead to elevated isotope values of phytoplankton, which can be traced in SPOM and can provide insight into the input of wPOM to sediments (Nakatsuka et al. 1992, Lehmann et al. 2004). (3) Biomass of macrobenthic taxa and their $\delta^{13} \mathrm{C}$ and $\delta^{15} \mathrm{~N}$ values were determined during pre-bloom, bloom and post-bloom conditions to gain insight into the macrobenthic community and trophic structure that developed at the different stations.

\section{MATERIALS AND METHODS}

Study site and cruises. Both stations are located on the BCS in the southern North Sea (Fig. 1). Stn $330_{\text {COARSE }}$ is located offshore $\left(51^{\circ} 26.0^{\prime} \mathrm{N}_{i} 02^{\circ} 48.5^{\prime} \mathrm{E}\right)$ at a depth of $20 \mathrm{~m}$ and consists of medium sands with a silt content of $0.2 \%$, median grain size of $360 \mu \mathrm{m}$ and $228 \mu \mathrm{m}$ as

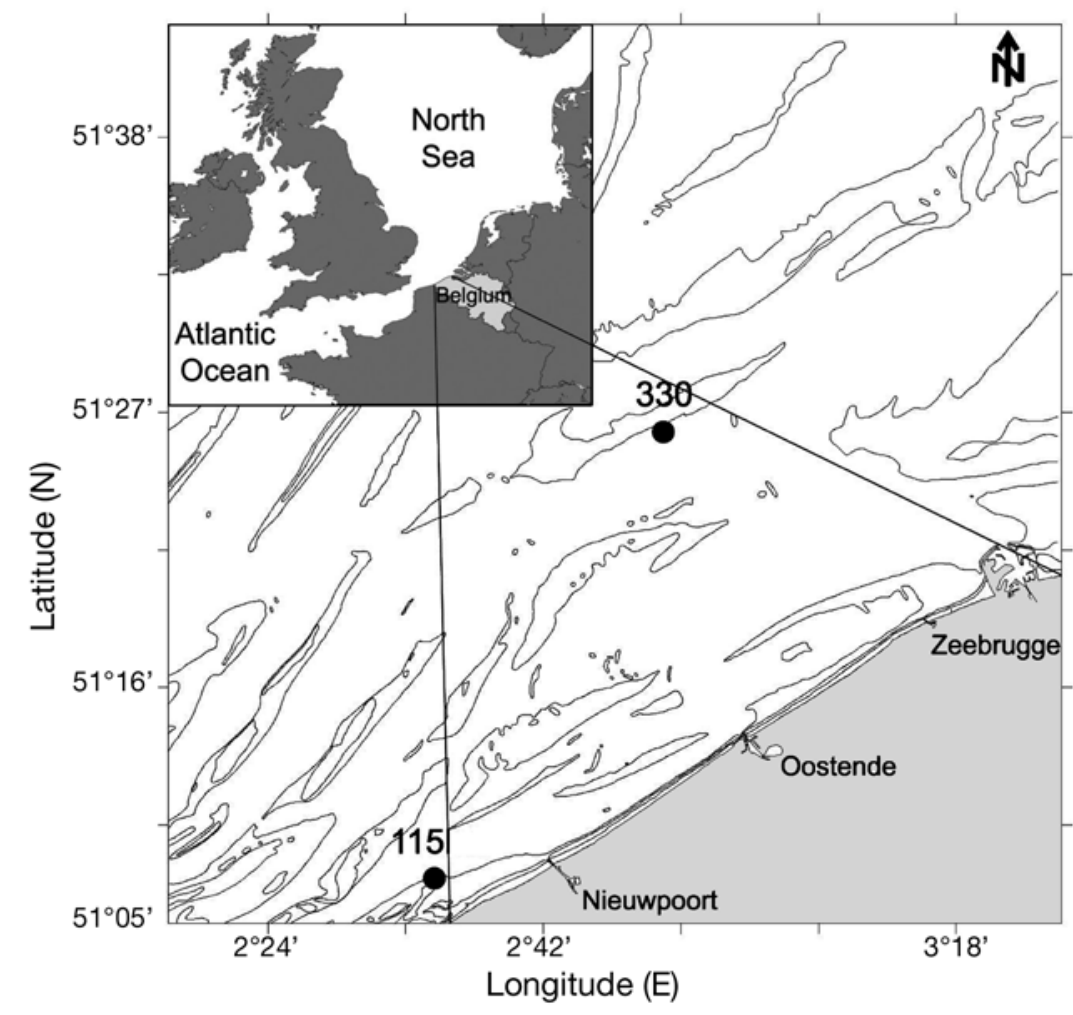

Fig. 1. Location of fine coastal sediment $\left(115_{\mathrm{FINE}}\right)$ and coarse offshore sediment $\left(330_{\text {COARSE }}\right)$ stations on the Belgian Continental Shelf 
the 10th percentile of the grain distribution $\left(d_{10}\right)$. Sediment permeability is estimated at $5.3 \times 10^{-10} \mathrm{~m}^{2}$, based on the empirical relation from Hazen:

$$
k_{\mathrm{H}}=1.019 \times 10^{3} \times d_{10}^{2} \times v
$$

in which $v$ is the kinematic viscosity (Rusch et al. 2001). Oxygen penetration was $>1 \mathrm{~cm}$ throughout the year (author's unpubl. data).

Stn $115_{\mathrm{FINE}}$ is located close to the coast $\left(51^{\circ} 09.2^{\prime} \mathrm{N}\right.$; $02^{\circ} 37.2^{\prime} \mathrm{E}$ ) at $13 \mathrm{~m}$ water depth and has a silt content of $14 \%$, median grain size of $180 \mu \mathrm{m}$ and $d_{10}$ of $38 \mu \mathrm{m}$. The estimated sediment permeability is $1.5 \times 10^{-11} \mathrm{~m}^{2}$, and oxygen penetration was $<5 \mathrm{~mm}$ during the bloom and post-bloom conditions.

Sampling at 2 levels of intensity was conducted from October 2002 through October 2003. First, during monthly monitoring campaigns, the water column was sampled for concentrations of chl $a$, particulate organic carbon (wPOC), particulate organic nitrogen (wPON), $\delta^{13} \mathrm{C}$-wPOC and $\delta^{15} \mathrm{~N}$-wPON. The sediment was sampled for concentrations of $\mathrm{chl} a$, particulate organic carbon (sPOC), particulate organic nitrogen (sPON), $\delta^{13} \mathrm{C}$-sPOC and $\delta^{15} \mathrm{~N}$-sPON. In addition, the meiobenthic community of both stations was characterized monthly (Franco et al. 2008b).

Second, 3 intensive campaigns were held in February, April and October 2003, during which additional variables were measured. The meiobenthic community was sampled for $\delta^{13} \mathrm{C}$ and $\delta^{15} \mathrm{~N}$ values at the taxon level (Franco et al. 2008b) and the macrobenthic community was sampled for density, biomass, $\delta^{13} \mathrm{C}$ and $\delta^{15} \mathrm{~N}$ values at taxa level.

Sampling and analytical procedures. Water column samples were taken from $3 \mathrm{~m}$ below the water surface and approximately $1 \mathrm{~m}$ above the sediment-water interface with a 101 Niskin bottle mounted on the CTD wire. The sampled water was filtered on precombusted GF/C filters for chl $a$, wPOM and stable isotope values of wPOM ( 500 $\left.\mathrm{ml} \mathrm{filter}^{-1}\right)$. The filters for chl a determination were frozen onboard $\left(-20^{\circ} \mathrm{C}\right)$ and stored at $-80^{\circ} \mathrm{C}$ in the laboratory. Filters for wPOM measurements were stored frozen onboard $\left(-20^{\circ} \mathrm{C}\right)$ and freeze dried in the laboratory.

Sediment was collected with a Reineck box core $\left(180 \mathrm{~cm}^{2}\right)$ during the monthly campaigns and with a large box core $\left(804 \mathrm{~cm}^{2}\right)$ during the intensive campaigns. Box cores with a seemingly undisturbed surface were sub-sampled by manually inserting smaller Plexiglas or Perspex cores $(10 \mathrm{~cm} \varnothing)$ and kept in a temperature-controlled water bath. Three sediment cores were sliced at $1 \mathrm{~cm}$ depth intervals down to $10 \mathrm{~cm}$ for determination of sedimentary chl a.

Chl a concentrations on filters and weighed sediment samples were determined using HPLC (Gilson) following Wright \& Jeffrey (1997). Chl a concentrations in the water column were converted to volumetric units of sampled water.

For sPOC/sPON and $\delta^{13} \mathrm{C}-\mathrm{sPOC} / \delta^{15} \mathrm{~N}-\mathrm{sPON}$ analyses, the top 0-1 cm interval (and 4-5 cm interval on intensive campaigns) was sliced from the cores, dried at $60^{\circ} \mathrm{C}$ and ground for homogenization before subsequent analysis.

The methodological description for the determination of meiobenthic stable isotope analysis is given in Franco et al. (2008b). Briefly, cores were sliced and stored onboard at $-20^{\circ} \mathrm{C}$. Slices were thawed in the laboratory and sorted to taxon level, transferred into silver cups and stored at $-20^{\circ} \mathrm{C}$ for isotope analysis. Typically, 60 nematodes were used for $\delta^{15} \mathrm{C}$ analysis and 160 for $\delta^{15} \mathrm{~N}$.

The macrobenthic community was sampled with 2 or 3 large Plexiglas cores (14 $\mathrm{cm} \varnothing, 10 \mathrm{~cm}$ depth) from the box core. The samples were sieved $(500 \mu \mathrm{m})$ on board prior to storage at $-20^{\circ} \mathrm{C}$. In the laboratory, the macrobenthic samples were thawed and sorted under a binocular to species level. Specimens were cleaned of adhering debris and counted at species or genus level. Specimens of shell-bearing species were physically separated from their shell. Part of the flesh sample was ground for thorough homogenization and a subsample was transferred to a silver cup that was stored for isotope analysis. Another part was used to determine ash-free dry weight (AFDW) of a known number of specimens of a certain species. The AFDW per individual was converted to $\mathrm{C}$ assuming a $\mathrm{C}$ :AFDW ratio of 0.4 and used to convert total density of a species to biomass. Macrobenthic species were assigned to a feeding group based on classifications in the specialized literature.

The trophic level (TL) of a macrobenthic consumer was estimated as:

$$
\mathrm{TL}_{\text {consumer }}=2+\left(\delta^{15} \mathrm{~N}_{\text {consumer }}-\delta^{15} \mathrm{~N}_{\text {base }}\right) / \Delta^{15} \mathrm{~N}
$$

(Post 2002), in which the $\delta^{15} \mathrm{~N}_{\text {base }}$ is the $\delta^{15} \mathrm{~N}$ value of the primary consumer (i.e. TL 2) and $\Delta^{15} \mathrm{~N}$ is the trophic fractionation associated with each TL. The generally accepted fractionation factor of $3.4 \%$ was adopted for $\Delta^{15} \mathrm{~N}$ (Minagawa \& Wada 1984, Post 2002). The average $\delta^{15} \mathrm{~N}$ value of the suspensionfeeding bivalves Abra alba and Venerupis pullastra defined the $\delta^{15} \mathrm{~N}_{\text {base }}$.

All stable isotope measurements were performed on a Fisons CN elemental analyzer coupled online, via a Finnigan ConFlo II interface, with an isotope ratio mass spectrometer (Thermo Finnigan MAT DELTA Plus). The stable isotope ratio of a sample is expressed as per mille deviation (\%) from the isotope ratio of a reference material and is calculated as:

$$
\delta X(\%)=\left[\left(R_{\text {sample }}\right) /\left(R_{\text {reference }}\right)-1\right] \times 1000
$$


in which $X$ is ${ }^{13} \mathrm{C}$ or ${ }^{15} \mathrm{~N}, R_{\text {sample }}$ is the ${ }^{13} \mathrm{C}:{ }^{12} \mathrm{C}$ or ${ }^{15} \mathrm{~N}:{ }^{14} \mathrm{~N}$ ratio of the sample, and $R_{\text {reference }}$ is the isotope ratio of the reference material (Vienna Pee Dee Belemnite for C, and atmospheric $\mathrm{N}_{2}$ for $\mathrm{N}$ ). All samples were acidified with $5 \% \mathrm{HCl}$ to ensure carbonate removal. Reproducibility of natural samples was $0.2 \%$.

Statistical tests were conducted in the freely available environment for statistical computing $\mathrm{R}$ v. 2.7.2 (R Development Core Team) and were based on a linear model using general least squares (function $\mathrm{gls}$ in R-package nlme) with station and sampling date as factors, because this method is insensitive to omissions in the dataset (Pinheiro \& Bates 2000). Also, Figs. 2-4 were produced with the R software. Contours in Fig. 2 were produced with the R software. Contours in Fig. 2 were the least-squares surface trend function surf.ls from the R-package spatial (Venables \& Ripley 2002). Data presented are mean values \pm SD unless otherwise stated.

\section{RESULTS}

\section{Water column and sediment data}

The chl a dynamics in the water column were comparable throughout the year at Stn $115_{\mathrm{FINE}}$ and Stn $330_{\text {COARSE, }}$ but concentrations were higher at Stn $115_{\text {FINE }}$ (Fig. 2). Concentrations in the period October 2002 to January 2003 were between 2.53 and $4.01 \mathrm{mg} \mathrm{m}^{-3}$ for Stn $115_{\mathrm{FINE}}$ and between 0.69 and $2.38 \mathrm{mg} \mathrm{m}^{-3}$ for Stn $330_{\text {COAREE}}$ and increased sharply
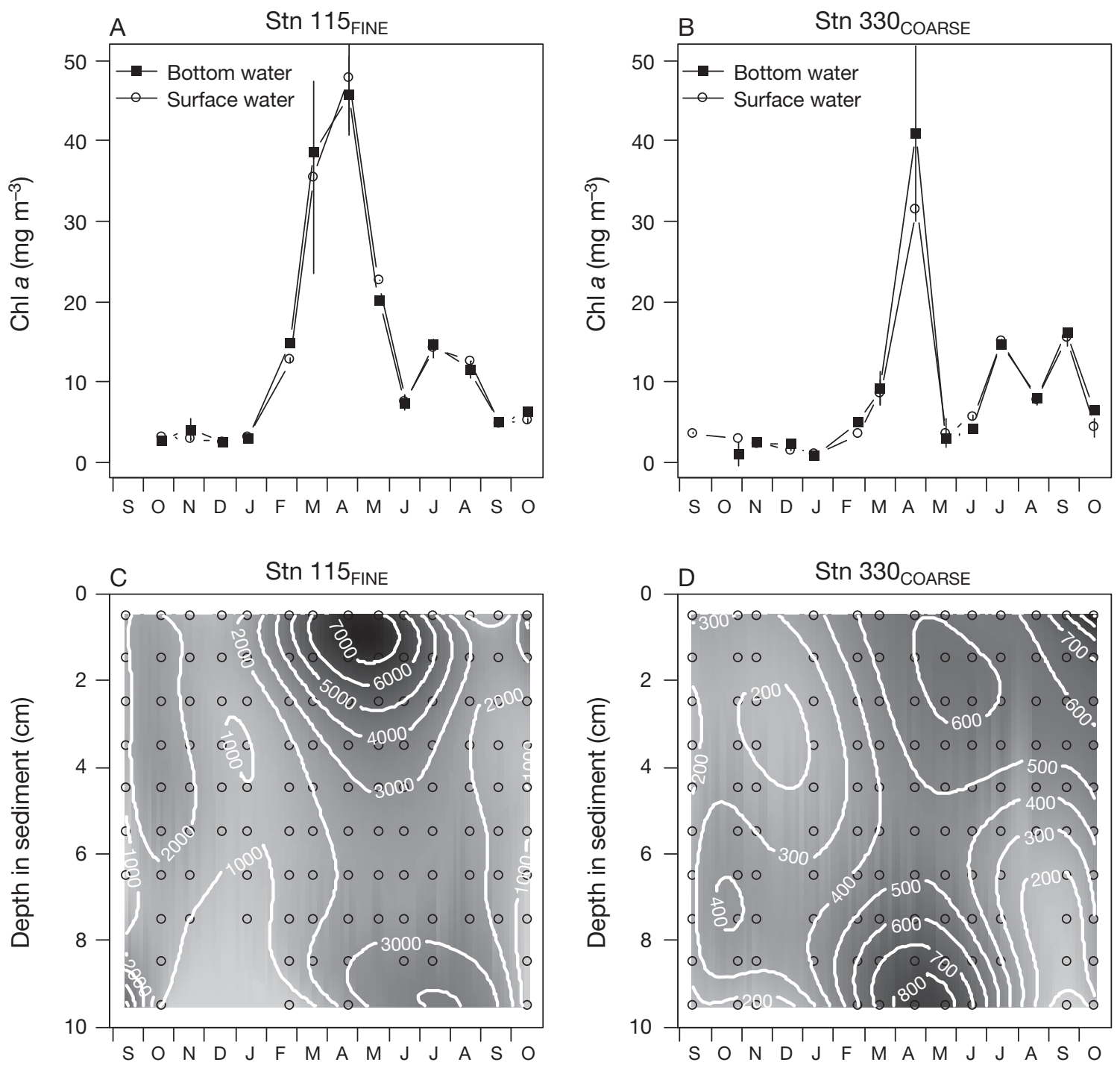

Month

Fig. 2. Chlorophyll a (chl a) concentrations (mean $\pm \mathrm{SD}$ ) in the water column at (A) Stn $115_{\mathrm{FINE}}$ and (B) Stn $330_{\mathrm{COARSE}}$ and in the sediment $\left(\mathrm{ng} \mathrm{g}^{-1}\right)$ at (C) Stn $115_{\mathrm{FINE}}$ and (D) Stn $330_{\mathrm{COARSE}}$ from September 2002 to October 2003 
during the spring bloom (maxima of 45.7 and $41.0 \mathrm{mg}$ $\mathrm{m}^{-3}$, respectively). The months following the spring bloom (May to October 2003) were characterized by chl a concentrations of 4.89 to 20.1 and 2.80 to $16.1 \mathrm{mg}$ $\mathrm{m}^{-3}$ for Stn $115_{\mathrm{FINE}}$ and Stn $330_{\mathrm{COARSE}}$, respectively. The chl $a$ inventory (i.e. concentration $\times$ water depth in $\mathrm{mg}$ chl a m${ }^{-2}$ ) was not significantly different between stations $\left(F_{1,77}=0.35, \mathrm{p}=0.55\right), 175 \pm 179$ at Stn $115_{\mathrm{FINE}}$ and $169 \pm 192$ at Stn $330_{\text {COARSE }}$, but sampling events differed significantly $\left(F_{12,77}=134.7, \mathrm{p}<0.0001\right)$, and also the interaction term was significant $\left(F_{12,77}=22.2, \mathrm{p}<\right.$ 0.0001).

The dynamics of chl $a$ in the water column are reflected in the sediment at Stn $115_{\mathrm{FINE}}$ (Fig. 2A,C), where low concentrations were measured during the pre-bloom period (average for top $10 \mathrm{~cm}$ was $1794 \pm$

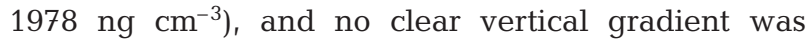
apparent. Chl a deposition was evident during and after the phytoplankton bloom, resulting in a vertical profile with $5969 \pm 4106 \mathrm{ng} \mathrm{cm}^{-3}$ in the top $0-1 \mathrm{~cm}$ and $2031 \pm 991 \mathrm{ng} \mathrm{cm}^{-3}$ in the $6-7 \mathrm{~cm}$ layer (average from March to June). This gradient vanished in the following months, when chl a concentrations dropped to $1114 \pm$ $1022 \mathrm{ng} \mathrm{cm}^{-3}$ (sediment column average in October). The sedimentary chl a dynamics were different at Stn $330_{\text {COARSE}}$ : no clear vertical gradient developed during the bloom and post-bloom period (Fig. 2), but the depth averages varied seasonally, from $320 \pm 271 \mathrm{ng}$ $\mathrm{cm}^{-3}$ in pre-bloom to $576 \pm 476 \mathrm{ng} \mathrm{cm} \mathrm{cm}^{-3}$ in bloom and $539 \pm 392 \mathrm{ng} \mathrm{cm}^{-3}$ in post-bloom conditions. A pairwise comparison over all layers and sampling events indicates that the sedimentary chl a concentration was 6.8 times lower at Stn $330_{\text {COARSE }}$ than at Stn $115_{\mathrm{FINE}}$.

Organic carbon and nitrogen contents were not very variable in the top $0-1 \mathrm{~cm}$ layer at either station, although at Stn $115_{\mathrm{FINE}}$ in April organic carbon and nitrogen content peaked at $1.30 \pm 0.94 \mathrm{wt} \%$ and $0.20 \pm 0.14 \mathrm{wt} \%$, respectively. During the rest of the year, organic carbon and nitrogen content averaged $0.14 \pm 0.04 \mathrm{wt} \%$ and $0.024 \pm$ $0.009 \mathrm{wt} \%$, respectively, at Stn $115_{\mathrm{FINE}}$. At Stn $330_{\text {COARSE }}$ the annual averaged organic carbon and nitrogen content was $0.064 \pm 0.03$ and $0.013 \pm 0.010$, respectively. Organic carbon content differed significantly between stations irrespective of the inclusion of the peak data in April $\left(F_{1,37}=64.0, \mathrm{p}<0.0001\right.$ versus $\left.F_{1,41}=13.0, \mathrm{p}<0.001\right)$, but sampling date and the interaction term were only significant when the April peak was included in the analysis $\left(F_{9,37}=1.04, \mathrm{p}=0.42\right.$ versus $F_{10,41}=3.97, \mathrm{p}<0.001$ for sampling date and $F_{9,37}=1.14, \mathrm{p}=0.36$ versus $F_{10,41}=$ 4.42 , p $<0.001$ for the interaction term). Also, organic nitrogen differed significantly between stations $\left(F_{1,37}=\right.$ $31.3, \mathrm{p}<0.0001$ versus $\left.F_{1,42}=11.6, \mathrm{p}<0.01\right)$ and sampling date $\left(F_{9,37}=6.08, \mathrm{p}<0.0001\right.$ versus $\left.F_{10,41}=3.79, \mathrm{p}<0.01\right)$ irrespective of the April peak, whereas the interaction term was only significant when the April peak was in- cluded $\left(F_{9,37}=1.95, \mathrm{p}=0.07\right.$ versus $F_{10,41}=4.58, \mathrm{p}<$ $0.001)$. Molar C:N ratios averaged $6.7 \pm 1.4$ at $\mathrm{Stn} 115_{\mathrm{FINE}}$ and $7.1 \pm 4.4$ at Stn $330_{\text {COARSE }}$ and were not significantly different between stations $\left(F_{1,61}=0.21, \mathrm{p}=0.65\right)$.

In the water column, $\delta^{13} \mathrm{C}$-wPOM dynamics were similar at the stations, although the variability was higher at Stn $330_{\text {COARSE }}$ than at Stn $115_{\mathrm{FINE}}$ (Fig. 3A,B). $\delta^{13} \mathrm{C}$-wPOM was constant during the pre-bloom period, between $-22.4 \pm 0.14$ and $-21.5 \pm 0.14 \%$ at Stn $115_{\mathrm{FINE}}$ and between $-24.4 \pm 0.20$ and $-21.6 \pm$ $0.21 \%$ at Stn $330_{\text {COARSE}}$, and increased to peak values of $-19.7 \pm 1.11 \%$ at $\operatorname{Stn} 115_{\mathrm{FINE}}$ and $-19.5 \pm 1.00 \%$ at Stn $330_{\text {COARse }}$ (Fig. 3A,B). Subsequently, $\delta^{13} \mathrm{C}-\mathrm{wPOM}$ values dropped below $-24 \%$ at both stations and then rose continuously in the late summer and autumn to $-20.5 \pm 0.25$ at $\operatorname{Stn} 115_{\mathrm{FINE}}$ and $-20.6 \pm 0.21$ at Stn $330_{\text {COARSE }}$ (Fig. 3A,B). The dynamics of $\delta^{13} \mathrm{C}$-sPOM in the $0-1 \mathrm{~cm}$ sediment layer mirrored those of $\delta^{13} \mathrm{C}$ wPOM at Stn $115_{\text {FINE }}$, but with a time lag of approximately 1 to 2 mo (Fig. $3 \mathrm{~A}$ ). $\delta^{13} \mathrm{C}$-sPOM differed significantly between the $0-1$ and $4-5 \mathrm{~cm}$ layers $\left(F_{1,12}=5.34\right.$, $\mathrm{p}<0.05)$ and sampling dates $\left(F_{2,12}=15.5, \mathrm{p}<0.001\right)$ at Stn $115_{\mathrm{FINE}}$, although on average the top layer was only $0.53 \%$ heavier. Similar to Stn $115_{\text {FINE, }}$ at Stn $330_{\text {COARSE }}$ $\delta^{13} \mathrm{C}$-sPOM in the $0-1 \mathrm{~cm}$ sediment layer tracked $\delta^{13} \mathrm{C}$ wPOM during the pre-bloom and bloom conditions (Fig. 3B). In the post-bloom period, however, $\delta^{13} \mathrm{C}$ sPOM increased to $-17.8 \pm 0.84$ in October (Fig. 3B) $\delta^{13} \mathrm{C}-\mathrm{sPOM}$ at Stn $330_{\text {COARSE }}$ differed significantly between sampling dates $\left(F_{2,10}=2.76, \mathrm{p}=0.11\right)$, but not between sediment layers $\left(F_{1,10}=1.75, \mathrm{p}=0.21\right)$.

$\delta^{15} \mathrm{~N}$-wPOC and $\delta^{15} \mathrm{~N}$-sPOM values at Stn $115_{\mathrm{FINE}}$ showed less pronounced seasonal patterns, although $\delta^{15} \mathrm{~N}$-sPON was depleted in the months November 2002 to March 2003 (3.9 to 5.0\%), as compared to the period April to October (6.8 to 8.5\%), except for July (Fig. 3C). The $\delta^{15} \mathrm{~N}$ dynamics of wPOM and sPOM were highly variable at Stn $330_{\text {COARSE }}$ and did not show a seasonal trend (Fig. 3B,D). $\delta^{15} \mathrm{~N}$ of sPOM, however, increased over the sampled period from 4.9 to $15.9 \%$. $\delta^{15} \mathrm{~N}$-wPOM was higher at Stn $115_{\mathrm{FINE}}$ than $\delta^{15} \mathrm{~N}-\mathrm{SPOM}$, except for October 2003, and a pairwise comparison reveals that on average $\delta^{15} \mathrm{~N}$ of $\mathrm{WPOM}$ is $3.4 \pm 3.2 \%$ higher than sPOM at Stn $115_{\mathrm{FINE}}$ (Fig. 3C). A pairwise comparison at Stn $330_{\text {COARSE }}$ indicates that $\delta^{15} \mathrm{~N}$-wPOM was on average $2.3 \pm 5.3 \%$ higher than $\delta^{15} \mathrm{~N}$-sPOM, but also that $\delta^{15} \mathrm{~N}$-wPOM was higher on 7 samplings and lower on 4 samplings (Fig. 3D). $\delta^{15} \mathrm{~N}$-sPOM differed significantly between the layers $\left(F_{1,12}=7.11, \mathrm{p}<\right.$ $0.05)$ and sampling dates $\left(F_{2,12}=51.5, \mathrm{p}<0.0001\right)$ at Stn $115_{\text {FINE, }}$ with the top layer being on average $-1.3 \%$ depleted as compared to the deeper layer. At Stn $330_{\text {COARSE }}$ no significant differences between sediment layers $\left(F_{1,10}=0.002, \mathrm{p}=0.96\right)$ and sampling dates $\left(F_{2,10}=2.76, \mathrm{p}=0.11\right)$ were found. 

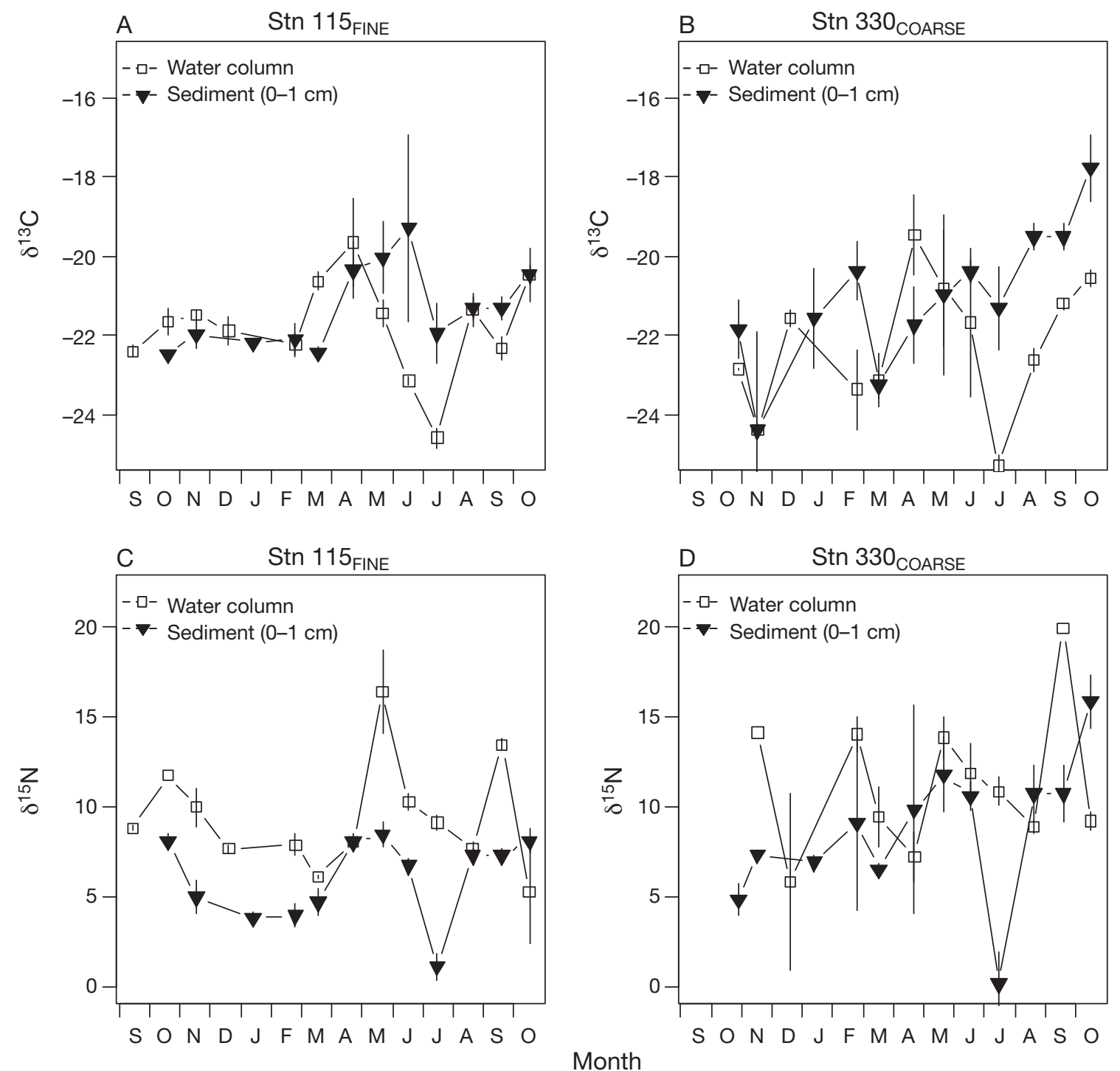

Fig. 3. Annual dynamics (mean $\pm \mathrm{SD}$ ) of $\delta^{13} \mathrm{C}$ in particulate organic carbon in the water column $\left(\delta^{13} \mathrm{C}\right.$-wPOC) and $0-1 \mathrm{~cm}$ sediment layer $\left(\delta^{13} \mathrm{C}\right.$-sPOC) at (A) Stn $115_{\mathrm{FINE}}$ and (B) Stn $330_{\text {COARSE}}$, and of $\delta^{15} \mathrm{~N}$ in the water column $\left(\delta^{15} \mathrm{~N}\right.$-wPOC) and $0-1 \mathrm{~cm}$ sediment layer $\left(\delta^{15} \mathrm{~N}\right.$-sPOC) at (C) Stn $115_{\mathrm{FINE}}$ and (D) Stn $330_{\mathrm{COARSE}}$ from September 2002 to October 2003

\section{Macrobenthos community}

Macrobenthic biomass was lowest in February at Stn $115_{\text {FINE }}\left(5.7 \pm 3.9 \mathrm{~g} \mathrm{C} \mathrm{m}^{-2}\right)$ and Stn $330_{\text {COARSE }}\left(0.39 \mathrm{~g} \mathrm{C}^{-2}\right.$ $\left.\mathrm{m}^{-2}\right)$, but increased toward April $\left(62 \pm 43.7 \mathrm{~g} \mathrm{C} \mathrm{m}^{-2}\right.$ at Stn $115_{\mathrm{FINE}}$ and $2.3 \pm 3.9 \mathrm{~g} \mathrm{C} \mathrm{m}^{-2}$ at Stn $330_{\text {COAREE }}$ ) and was highest in October at Stn $115_{\mathrm{FINE}}\left(78 \pm 60 \mathrm{~g} \mathrm{C} \mathrm{m}^{-2}\right)$ and Stn $330_{\text {COARSE }}\left(3.8 \pm 2.4 \mathrm{~g} \mathrm{C} \mathrm{m}^{-2}\right.$; Tables $\left.1 \& 2\right)$. On average, macrobenthic biomass was 20 times higher at Stn $115_{\mathrm{FINE}}$ than at Stn $330_{\mathrm{COARSE}}$. Despite the high variability (Tables $1 \& 2$ ), macrobenthic biomass was significantly different between the 2 stations $\left(F_{1,10}=5.02\right.$, $\mathrm{p}<0.05)$, but not between sampling dates $\left(F_{1,10}=2.29\right.$, $\mathrm{p}=0.15)$.
The macrobenthos at Stn $115_{\mathrm{FINE}}$ was dominated by Bivalvia (36, 62 and 50\% in February, April and October, respectively) and Anthozoa (32\% in April and $25 \%$ in October) (Table 1). The class Bivalvia consisted of the species Abra alba, Mysella bidentata, Venerupis pullastra and the razor shell Ensis ensis. The anemone Sagartia troglodytes was the only anthozoan species. The class Polychaeta was not dominant in biomass (2.6, 3.7 and $12.1 \mathrm{~g} \mathrm{C} \mathrm{m}^{-2}$ in February, April and October, respectively), but was the most species-rich with 19 species. Species that dominated the polychaete biomass were Nephtys hombergii, Heteromastus filiformis and Lanice conchilega. In terms of feeding type, biomass was dominated by suspension feeders 


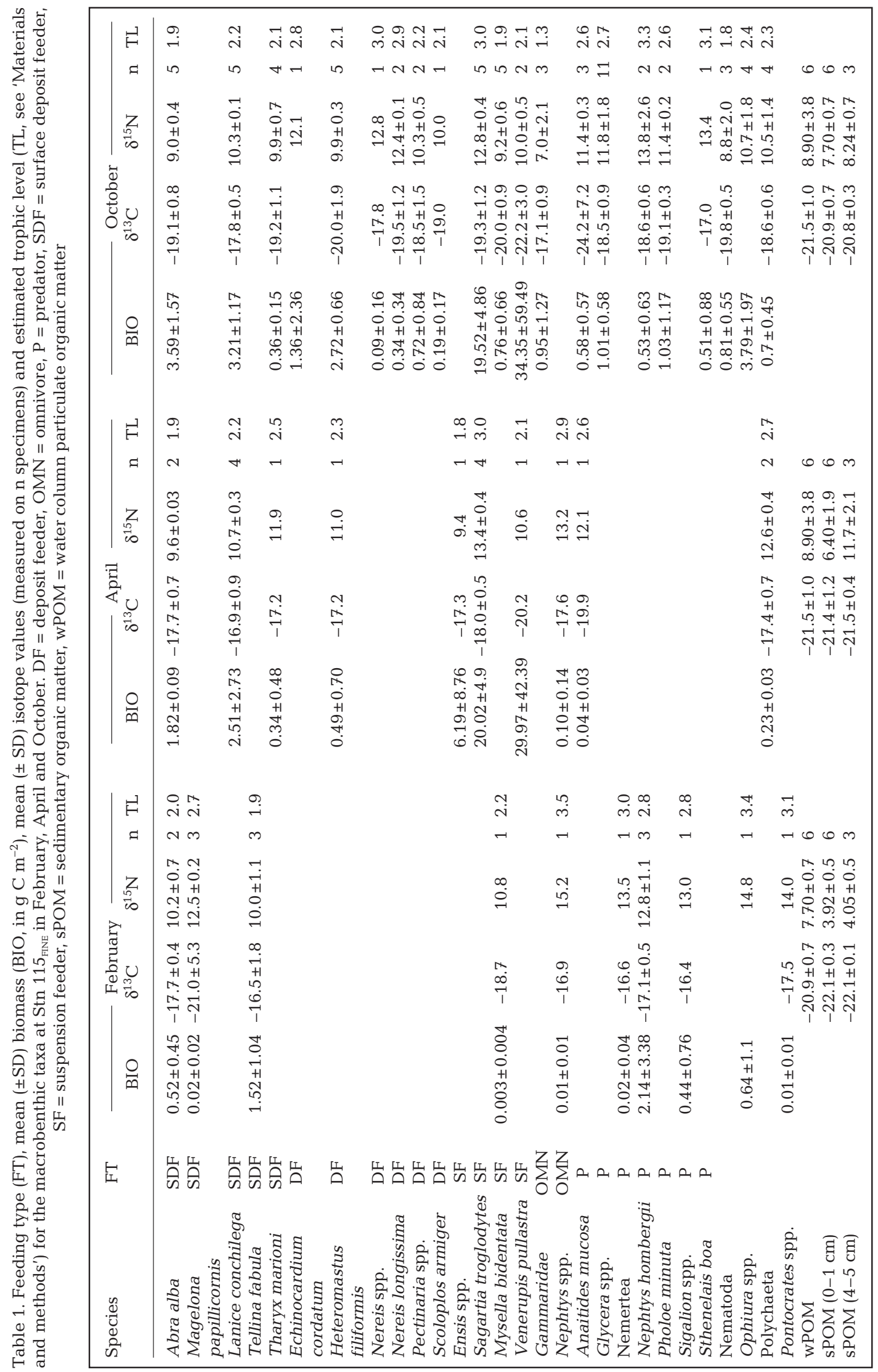




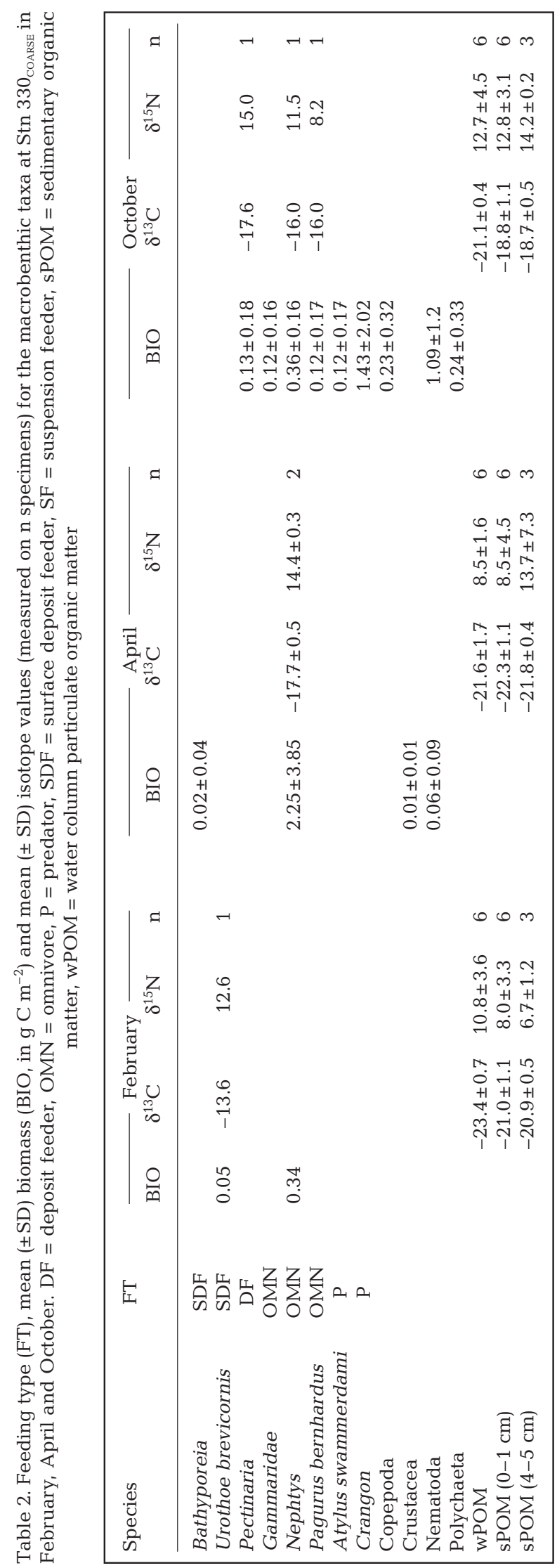

(91\% and $70 \%$ in April and October, respectively), followed by surface deposit feeders $(36,8$ and $9 \%$ in February, April and October, respectively) and predators (45 and $6 \%$ in February and October, respectively; Table 1).

The macrobenthic community at Stn $330_{\text {COARSE }}$ was dominated by polychaetes, which represented 87 , 96 and $19 \%$ of the total macrobenthic biomass in February, April and October, respectively (Table 2). Nephtys spp. dominated the polychaete biomass, but in October Pectinaria spp. and some unidentified species also contributed. Crustacea was an important fraction of the biomass only in October (53\%), when it was composed of Atylus swammerdami, Crangon crangon, Pagurus bernhardus, Gammaridae spp. and Copepoda spp. (Table 2). Omnivores were important in all samples (87, 96 and 16\% in February, April and October, respectively) and predators were important in October (40\%; Table 2). Nephtys spp. were the sole omnivores in February and April, but in October the hermit crab P. bernhardus and Gammaridae spp. were present as well. Predators in October consisted of A. swammerdami and the shrimp C. crangon. Surface deposit feeders and deposit feeders together constituted only a very small fraction of the macrobenthic biomass $(12,1$, and $3 \%$ in February, April and October, respectively).

\section{$\delta^{13} \mathbf{C}$ and $\delta^{15} \mathbf{N}$ of macrobenthos}

The isotope values of the macrobenthic species at Stn $115_{\mathrm{FINE}}$ ranged from -24.2 to $-16.4 \%$ for $\delta^{13} \mathrm{C}$ and from 7.0 to $15.2 \%$ for $\delta^{15} \mathrm{~N}$ (Table 1, Fig. 4), respectively. In February, most $\delta^{13} \mathrm{C}$ values were between -18.7 and $-16.4 \%$, except for Magelona papillicornis, and were thereby 4 to $6 \%$ heavier than what would be expected from feeding on wPOM or sPOM (Fig. 4A). The omnivore Nephtys spp. and predators Nephtys hombergii, Sigalion spp. and Nemertea had $\delta^{15} \mathrm{~N}$ values that were 3 to $5 \%$ o heavier than those of the suspension feeder Mysella bidendata and the surface deposit feeders Tellina fibula and Abra alba (Fig. 4A). Consequently, the calculated TLs of the omnivore and predatory species were $>2.8$ (Table 1 ).

In April, the $\delta^{13} \mathrm{C}$ values of most species, except for Venerupis pullastra and Anaitides mucosa, were between -18.0 and $-16.9 \%$ (Table 1 ). Similar to the February values, the $\delta^{13} \mathrm{C}$ values of the organisms were heavier than would be expected from feeding on wPOM or sPOM. The difference was around 2.5 to $4.5 \%$, depending on the species (Fig. 4B). Most surface deposit feeders and suspension feeders had $\delta^{13} \mathrm{~N}$ values between 9.4 and $10.7 \%$, indicating a TL of $\sim 2$ 

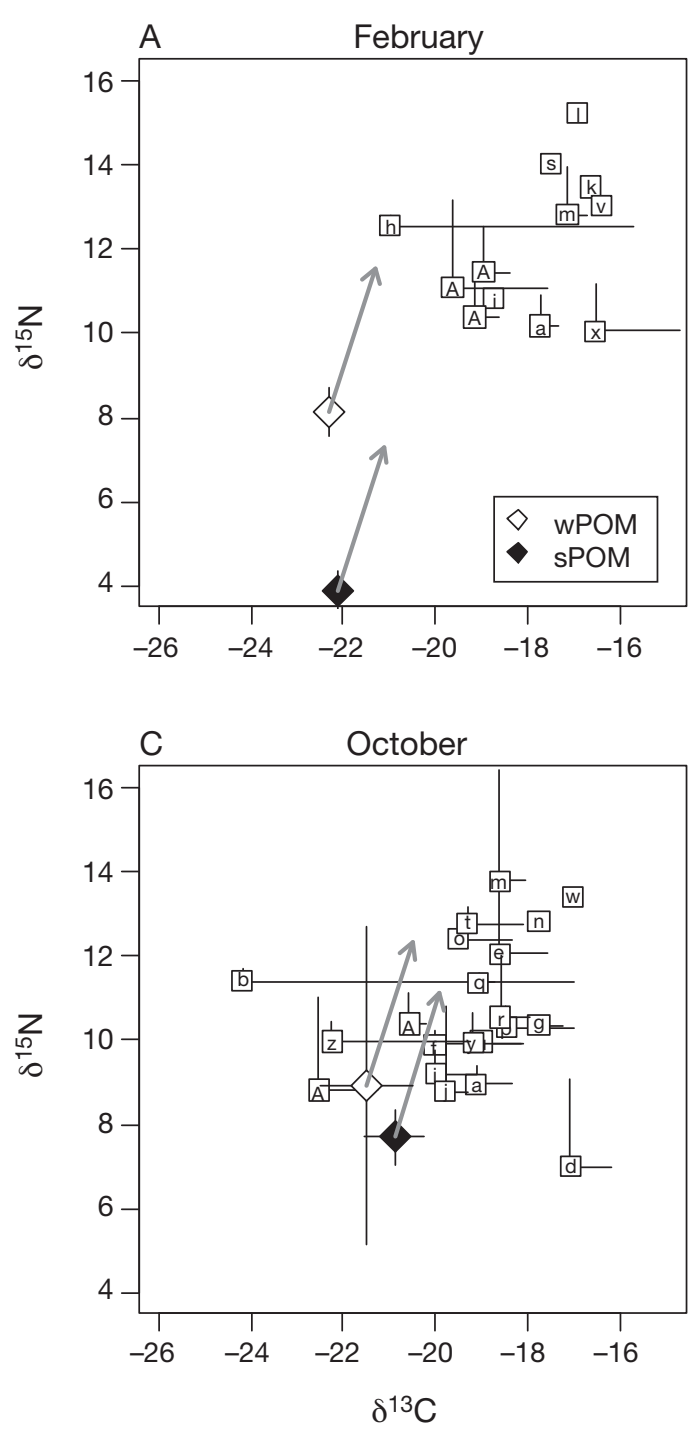

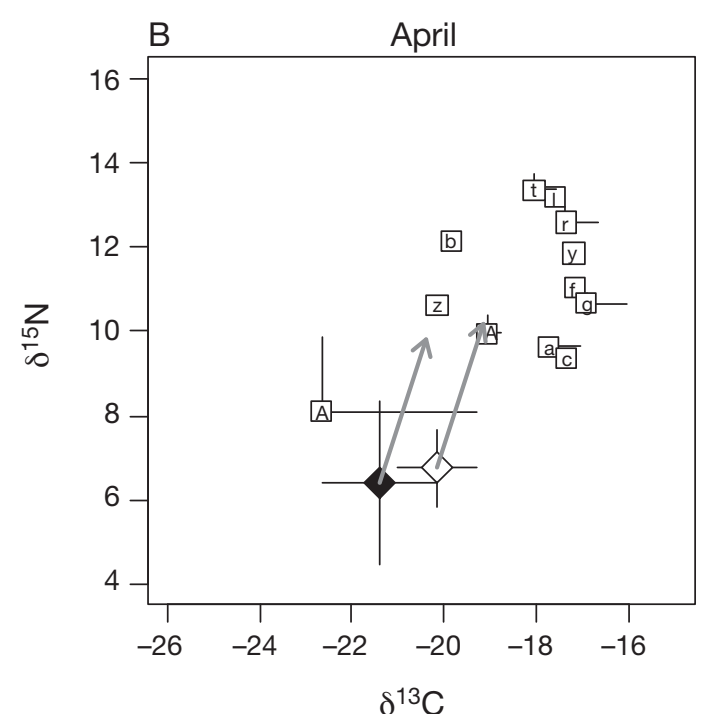

a Abra alba
b Anaitides mucosa
c Ensis spp.
d Gammaridae
e Glycera spp.
f Heteromastus filiformis
g Lanice conchilega
h Magelona papillicornis
i Mysella bidentata
j Nematoda
k Nemertea
I Nephtys spp.
m Nephtys hombergii
n Nereis spp.

- Nereis longissima

p Pectinaria spp.

q Pholoe minuta

$r$ Polychaeta

s Pontocrates spp.

t Sagartia troglodytes

u Scoloplos armiger

$\checkmark$ Sigalion spp.

w Sthenelais boa

$x$ Tellina fabula

y Tharyx marioni

z Venerupis pullastra

A Nematoda, Franco et al. 2008b

Fig. 4. Isotope values for macrobenthic taxa, water column particulate organic matter (wPOM) and sedimentary POM (sPOM) at Stn $115_{\mathrm{FINE}}$ in (A) February, (B) April and (C) October. Values for wPOM and sPOM are averages from data from the sampling month and the preceding month. The gray arrows indicate the expected isotope value of a consumer that depends completely on wPOM or sPOM using trophic fractionation factors for $\delta^{13} \mathrm{C}$ and $\delta^{15} \mathrm{~N}$ ('Materials and methods'). Standard deviations are given only 1 -sided for clarity of the figure. See Table 1 for source data. Note that ' $u$ ' is positioned below ' $y$ ', see Table 1 for raw values

(Table 1). The polychaete Tharyx marioni and the Polychaeta had elevated $\delta^{15} \mathrm{~N}$ values, indicating a TL of 2.5 and 2.7, respectively. Also, the suspension feeder Sagartia troglodytes, a burrowing anemone, had a $\delta^{15} \mathrm{~N}$ value of $13.4 \%$, equivalent to an estimated TL of 3.0 (Table 1).

In October, $\delta^{13} \mathrm{C}$ values ranged from -24.2 to $-17.0 \%$ (Table 1, Fig. $4 \mathrm{C}$ ). The $\delta^{13} \mathrm{C}$ values of benthic organisms overlapped with or differed by 1 to $3 \%$ from expected $\delta^{13} \mathrm{C}$ values when feeding on wPOM or sPOM (Fig. 4C \& 5). Most surface deposit feeders and suspension feeders had $\delta^{15} \mathrm{~N}$ values between 9 and $10.3 \%$ and were estimated to be at a TL $\geq 2.2$ (Table 1). However, the deposit-feeding polychaetes Nereis spp. and Nereis longissima had elevated $\delta^{15} \mathrm{~N}$ values of 12.4 and $12.8 \%$ with corresponding TLs of 3.0 and 2.9, respectively (Table 1 ). The anemone
Sagartia troglodytes had an estimated TL of 3.0 (Table 1), similar to the value in April. All predatory species had elevated $\delta^{15} \mathrm{~N}$ values and were assigned TLs of $>2.6$ (Table 1). The omnivores Gammaridae had a comparatively low $\delta^{15} \mathrm{~N}$ value of $7.0 \pm 2.1 \%$ (Table 1).

Due to the limited biomass at $\operatorname{Stn} 330_{\text {COArser }} \delta^{13} \mathrm{C}$ and $\delta^{15} \mathrm{~N}$ values could be obtained for only a few species (Table 2). Similar to the values at Stn $115_{\mathrm{FINE}}$, the $\delta^{13} \mathrm{C}$ values of the organisms were $>3 \%$ o heavier than would be expected from feeding on wPOM or sPOM (Table 2). Since no stable isotope values were collected from primary consumers at Stn $330_{\text {COARSE }}$ we did not calculate TL. However, it was surprising that the hermit crab Pagurus bernhardus, typically regarded as a scavenger, had $\delta^{15} \mathrm{~N}$ values that were lower than wPOM or sPOM in October (Table 2). 


\section{DISCUSSION}

\section{Sediment characteristics}

The sediments at Stn $115_{\mathrm{FINE}}$ and Stn $330_{\mathrm{COARSE}}$ differed in composition (silt content $14 \%$ versus $0.2 \%$ and medium grain size $180 \mu \mathrm{m}$ versus $360 \mu \mathrm{m}$, respectively), organic carbon content $(0.14 \pm 0.15$ versus $0.066 \pm 0.098 \mathrm{wt} \%)$, organic nitrogen content $(0.024 \pm$ 0.024 versus $0.014 \pm 0.023 \mathrm{wt} \%)$, oxygen penetration ( $<5 \mathrm{~mm}$ versus $>10 \mathrm{~mm}$ ) and estimated permeability $\left(1.5 \times 10^{-11} \mathrm{~m}^{2}\right.$ versus $\left.5.3 \times 10^{-10} \mathrm{~m}^{2}\right)$. Results from a study on a coarse modeling grid of $5 \times 5 \mathrm{~km}$ indicated that hydrodynamic conditions were comparable at both stations (Fettweis \& Van den Eynde 2003). We did not quantify in situ hydrodynamic conditions in our study, but the model results indicate that the observed differences in sediment composition were mostly due to a coastal high turbidity field rather than hydrodynamic conditions (Fettweis \& Van den Eynde 2003). We regard water column turbidity as the prime cause driving station differences and discuss how the input to and processing of organic matter from the water differs from this viewpoint in the remainder of this section. However, other factors that may co-vary with this turbidity field or small differences in hydrodynamics may also contribute to these differences.

\section{Chl $a$ in the water column and sediment}

The water column was strongly mixed vertically at both stations as evidenced by similar chl a concentrations in surface and bottom water (Fig. 2). This vertical mixing may indicate that hydrodynamic conditions are indeed similar at both stations. The spring algal bloom, with a dominance of Phaeocystis colonies (D. van Oevelen pers. obs.), in April to May is typical for the North Sea (Lancelot et al. 2005) and resulted in elevated sedimentary chl a concentrations (Fig. 2).

The chl a inventory of the water column (i.e. mg $\left.\mathrm{m}^{-2}\right)$ was similar at both stations $(175 \pm 179 \mathrm{mg} \mathrm{chl} \mathrm{a}$ $\mathrm{m}^{-2}$ at $\operatorname{Stn} 115_{\mathrm{FINE}}$ and $169 \pm 192$ at Stn $330_{\mathrm{COARSE}}$ ). Sediment oxygen consumption, determined on a monthly basis, was 2.3 to 3.2 times higher at Stn $115_{\mathrm{FINE}}$ than at Stn $330_{\text {COARse }}$ (P. Provoost \& K. Soetaert pers. comm.). This indicates that a higher fraction of algal biomass was degraded in the sediment at Stn $115_{\mathrm{FINE}}$ than at Stn $330_{\text {COARSE }}$ and that algal carbon mineralization was lower in the permeable sandy sediments than in the finer sediments. This is supported by the sedimentary chl a inventory, which was 6.8 times higher at Stn $115_{\text {FINE }}$ despite similar water column chl a inventories. Huettel \& Rusch (2000) experimentally investigated advective transport of chl a into defaunated sediments of different permeability in flume and chamber incubations. The chl a concentration was 1.4 times higher and the influx was 2.5 times higher in sediments with a permeability comparable to Stn $330_{\text {COARSE }}$ than in sediments with a permeability similar to Stn $115_{\mathrm{FINE}}$. Our results seem to be in contrast with these experimental studies, but the latter experiments focused on advective injection of algae and did not include biologically mediated input.

The passive deposition of algae and detritus may be expected to be of similar magnitude at both stations, because of the similarity in hydrodynamic conditions. The higher carbon input and mineralization at Stn $115_{\mathrm{FINE}}$ is reflected in a 20 times higher macrobenthic biomass that was dominated by filter-feeding bivalves in April and October (Fig. 2A,C). Bivalves filter large amounts of water and produce (pseudo)feces that increase the flux of organic carbon, chl $a$ and phaeopigments into the sediment (Kautsky \& Evans 1987, Smaal \& Zurburg 1997, Chiantore et al. 1998, Frechette $\&$ Bacher 1998). The straight profile and deep penetration of chl $a$ at $\operatorname{Stn} 330_{\text {COARSE }}$ is indicative of adjective injection of algal-derived material and strong sediment mixing (Huettel et al. 1996, Huettel \& Rusch 2000, D'Andrea et al. 2002). However, disturbance and sediment mobility at Stn $330_{\text {COARSE }}$ may prevent the development of a macrobenthic community (Ysebaert et al. 2000, Aller \& Aller 2004, Wlodarska-Kowalczuk et al. 2007). As a result, the low macrobenthic biomass and absence of suspension feeders implies that biologically mediated input is virtually lacking at Stn $330_{\text {COARSE }}$.

\section{$\delta^{13} \mathrm{C}$ and $\delta^{15} \mathrm{~N}$ dynamics in the water column and sediment}

$\delta^{13} \mathrm{C}$-wPOC had a pronounced seasonal signal at both stations (Fig. 3A,B), although the variability and scatter were higher at Stn $330_{\text {COARSE }}$. An increase in $\delta^{13} \mathrm{C}$-wPOC is frequently observed during the spring bloom (Nakatsuka et al. 1992, Sato et al. 2006) and can be attributed to a reduced isotope fractionation with respect to the inorganic carbon source at higher specific growth rates (Laws et al. 1995). The subsequent reduction and dip in $\delta^{13} \mathrm{C}$-wPOC can be caused by (1) a decrease in specific growth rate of phytoplankton due to nutrient limitation, leading to increased isotope fractionation (Laws et al. 1995) or (2) a change in phytoplankton composition that fixes relatively more of the depleted $\mathrm{CO}_{2}(\mathrm{aq})$ than of $\mathrm{HCO}_{3}^{-}$or has a different fractionation factor. Species-specific differences are likely to contribute to the $\delta^{13} \mathrm{C}$-wPOC dynamics, since the phytoplankton community changes seasonally between different diatom assemblages and Phaeocystis (Rousseau et al. 2002). 
$\delta^{15} \mathrm{~N}-\mathrm{wPON}$ at Stn $115_{\mathrm{FINE}}$ changed between months (Fig. 3C), although standard deviations of the monthly values are small. Overall, $\delta^{15} \mathrm{~N}-w \mathrm{PON}$ was higher in late spring, summer and early autumn than in winter and early spring. This can be explained by phytoplankton growth under nutrient-replete conditions in winter and depleted conditions in spring and summer (van der Zee \& Chou 2005). Phytoplankton fractionates against heavy ${ }^{15} \mathrm{~N}$ during assimilation of nitrate and ammonium (Waser et al. 1998), thereby enriching the $\delta^{15} \mathrm{~N}$ of the remaining substrate. $\mathrm{N}$ uptake from the enriched nutrient results in elevated $\delta^{15} \mathrm{~N}$ values of phytoplankton under nutrient depletion (Waser et al. 1998). Given the variability in the data, however, other factors also probably play a role in $\delta^{15} \mathrm{~N}$-wPON dynamics, such as switching between $\mathrm{N}$ sources with different $\delta^{15} \mathrm{~N}$ values and changes in the phytoplankton community.

The input of wPOM to the sediment is apparent at Stn $115_{\text {FINE }}$ in the $\delta^{13} \mathrm{C}$-sPOM and $\delta^{15} \mathrm{~N}$-sPOM values in the top layer of the sediment that track water column $\delta^{13} \mathrm{C}$ and $\delta^{15} \mathrm{~N}$ (Fig. 3A,C). The apparent time lag of 1 to 2 mo was probably due to the sedimentary carbon stock that dilutes newly deposited POC. Surprisingly, however, this time lag is not apparent in $\delta^{15} \mathrm{~N}$ (Fig. 3C). The isotope dynamics at $\mathrm{Stn} 330_{\text {COARSE }}$ show some coupling between the water column and the top layer of the sediment (Fig. 3B,D), but the scatter is much higher, which might be due to low levels of $\mathrm{C}$ and $\mathrm{N}$ in the sediment and high heterogeneity. The coupling between the water column and sediment at Stn $330_{\text {COARSE }}$ does not show a time lag, which is expected, since the POC content of the sediment was low $(0.064 \mathrm{wt} \%)$. It is, however, unclear why $\delta^{15} \mathrm{~N}$-sPOM at Stn $330_{\text {COARSE }}$ increased over the sampling period, whereas the $\delta^{15} \mathrm{~N}$ of wPOM was comparatively constant (Fig. 3D).

The isotope composition of organic matter may undergo diagenetic alterations when isotopically distinct pools have a different reactivity (Aller \& Blair 2004). Data on $\Delta^{14} \mathrm{C}$ and $\delta^{13} \mathrm{C}$ values of bulk and isolated fractions of wPOM suggest that the contribution of terrestrial organic matter to wPOM is too low to explain isotopic diagenetic alterations (Megens et al. 2001). $\delta^{13} \mathrm{C}$-sPOM closely tracked $\delta^{13} \mathrm{C}$-wPOM at Stn $115_{\mathrm{FINE}}$ (Fig. 3A) and the 0-1 cm layer was significantly, but on average only $0.53 \%$, heavier than at $4-5 \mathrm{~cm}$ sediment depth, indicating that minor isotopic alterations occurred. The high variability at Stn $330_{\text {COARSE }}$ masks any change in $\delta^{13} \mathrm{C}$ after its deposition and will therefore not be discussed. The $\delta^{15} \mathrm{~N}$ of organic matter typically increases during decomposition due to selective uptake or degradation (Altabet \& Francois 1994). This generality conflicts with our observed depletion of $3.4 \pm 3.2 \%$ of $\delta^{15} \mathrm{~N}-\mathrm{sPON}$ versus $\delta^{15} \mathrm{~N}-\mathrm{wPON}$ at Stn $115_{\text {FINE }}$ (Fig. 3C). Some oceanic sediment trap studies also show decreases of $\delta^{15} \mathrm{~N}-\mathrm{POM}$ during down- ward transport, but a feasible explanation is still to be found (Thunell et al. 2004 and references therein). The $\delta^{15} \mathrm{~N}$ isotope shift between wPOM and SPOM is consistent throughout the year, and we speculate that the isotopic shift might be induced by biological selection before or after deposition.

\section{Macrobenthic isotope values and community structure}

The isotope values of wPOM and sPOM (Fig. 4) did not differ sufficiently to distinguish between feeding on benthic and feeding on pelagic organic matter by the benthos. Instead, we used stable isotopes to investigate selective feeding, identify seasonal changes in the difference between $\delta^{13} \mathrm{C}$ of macrobenthic species and wPOM/sPOM, and validate presumed feeding strategies using $\delta^{15} \mathrm{~N}$-based TLs.

The macrobenthic $\delta^{13} \mathrm{C}$ values show 2 interesting features (Fig. 4): (1) the $\delta^{13} \mathrm{C}$ of macrobenthic taxa was heavier than what would be expected from feeding on wPOM and SPOM; and (2) this difference decreased from February to October.

The isotope values for wPOM and sPOM (Fig. 4 \& Table 1) are averages of data from the month of sampling and the preceding month to account for the time that organisms require to equilibrate with their food source. The adopted period of 2 to $2.5 \mathrm{mo}$ is sufficient, since laboratory studies of polychaetes show isotope equilibration after 40 to $60 \mathrm{~d}$ (Hentschel 1998). Although isotope equilibration can take $\sim 4$ mo for large bivalves (Fukumori et al. 2008), their tissue $\delta^{13} \mathrm{C}$ and $\delta^{15} \mathrm{~N}$ strongly resembled the isotope composition of the gut contents and thus the current diet during sampling. Moreover, oysters and scallops turned over $25 \%$ of their carbon in most organs within $15 \mathrm{~d}$ (Paulet et al. 2006). The isotope differences between wPOM/ sPOM and fauna can therefore not be explained by a lack of equilibration. The isotope difference between fauna and wPOM/ sPOM can also not be explained by another, isotopically heavy, carbon source such as microphytobenthos. The light extinction coefficient of $0.36 \mathrm{~m}^{-1}$ (Lancelot et al. 2005) is too high to allow light penetration to the sediments of both stations.

Details of a similar $\delta^{13} \mathrm{C}$ difference between benthic consumers and POM was reported in a recent literature review on data of a nearshore-offshore gradient (Nadon \& Himmelman 2006), where $\delta^{13} \mathrm{C}$ values of benthic consumers in offshore sediments were 3 to $6 \%$ heavier than $\delta^{13} \mathrm{C}$-POM. Such an isotope difference can be interpreted as selective feeding and/or assimilation of carbon from wPOM and/or sPOM. Selective assimilation was shown in an ${ }^{15} \mathrm{~N}$-enrichment study on bivalve diets in streams (Raikow \& Hamilton 2001). Selective feeding reinforces earlier conclusions that 
bulk organic matter content is a poor predictor of food availability for deposit-feeding and suspensionfeeding macrobenthos (Dauwe et al. 1999 and references therein). The similarity in $\delta^{13} \mathrm{C}(-20$ to $-17 \%$ ) among feeding types (Fig. 4) indicates that similar food sources or food sources with a similar isotope signature are selected. Alternatively, the trophic fractionation for $\delta^{13} \mathrm{C}$ is higher than the standard assumption of $1 \%$. Post (2002) finds the average trophic fractionation for $\delta^{13} \mathrm{C}$ to be small, but highly variable $(0.4 \pm 1.3 \%$ o. We therefore support the call from Nadon \& Himmelman (2006) for additional experiments to explain the observed isotope shift.

The difference in $\delta^{13} \mathrm{C}$ between macrobenthic organisms and sPOM/wPOM was highest in February and progressively declined toward October (Fig. 4). These seasonal differences may be due to compositional changes of the organisms throughout the year. Lipids have depleted $\delta^{13} \mathrm{C}$ values (DeNiro \& Epstein 1977), and higher lipid concentrations give rise to lower $\delta^{13} \mathrm{C}$ values (Lorrain et al. 2002). Lipids were not extracted from our samples before analysis and thus influenced $\delta^{13} \mathrm{C}$ values. Low lipid reserves in winter and early spring because of reserve utilization and spawning could explain the heavy faunal $\delta^{13} \mathrm{C}$ values (Fig. 4). The subsequent decrease in $\delta^{13} \mathrm{C}$ toward October is then explained by a replenishment of lipid reserves. Lorrain et al. (2002) detected similar seasonal dynamics in the $\delta^{13} \mathrm{C}$ difference between $\delta^{13} \mathrm{C}$-sPOM and tissue-specific $\delta^{13} \mathrm{C}$ values of scallops, but also during periods of constant lipid concentrations, and reserve dynamics alone were insufficient to explain the seasonal differences. Studies with a diet-controlled setup, such that $\mathrm{C}$ and ${ }^{13} \mathrm{C}$ balances can be constructed for different compounds, are needed to shed more light on the seasonal variation in the $\delta^{13} \mathrm{C}$ difference between organisms and their food.

The $\delta^{15} \mathrm{~N}$ values were used to determine trophic positions and verify suspected feeding modes (Table 1). All taxa with a predatory feeding type had high TLs of $\geq 2.6$, which validates their assigned feeding type. The high $\delta^{15} \mathrm{~N}$ values of the surface depositfeeding Magelona papillicornis and deposit-feeding polychaetes Nereis spp. and Nephtys spp. indicated predatory feeding. In particular, all polychaetes from suborder Phyllodocida (subclass Palpata, ordo Aciculata) had a TL of $\geq 2.6$. Other deposit, surface deposit and suspension feeders were primary consumers with estimated TLs of $\sim 2$ (Table 1). TLs were consistent among seasons (Table 1), indicating comparative invariance of feeding habits.

Noteworthy is the anemone Sagartia troglodytes, which is a predator with a TL of 3 (Table 1). S. troglodytes is a passive suspension feeder that lives partly buried in the sediment. Sea anemones have been observed to actively select crustaceans during feeding (Sebens \& Koehl 1984), and gut content analysis of a burrowing sea anemone indicated that copepods are their primary prey (Holohan et al. 1998). S. troglodytes therefore probably preys on zooplankton. Anemones of similar size to those found at Stn $115_{\mathrm{FINE}}$ captured a minimum of 15 nauplii min $^{-1}$ in an experimental setup (Anthony 1997). Assuming that the summer population of $S$. troglodytes ( 250 specimens $\mathrm{m}^{-2}$, this study) preys on a similar amount of nauplii and assuming $0.00025 \mathrm{mg} \mathrm{C}^{\mathrm{C}}$ nuplius ${ }^{-1}$, anemone feeding would give a carbon flux of $\sim 2 \mathrm{~g} \mathrm{C} \mathrm{m}^{-2} \mathrm{~d}^{-1}$, which is 7 times the community mineralization in summer $\left(300 \mathrm{mg} \mathrm{C} \mathrm{m}^{-2}\right.$ $\mathrm{d}^{-1}$; P. Provoost \& K. Soetaert pers. comm.). The ingestion rate from laboratory conditions may overestimate in situ ingestion, because of fluctuating prey concentrations, interference with non-prey particles and discontinuous feeding. However, anemone respiration is estimated to be $250 \mathrm{mg} \mathrm{C} \mathrm{m}^{-2} \mathrm{~d}^{-1}$ (biomass is $25 \mathrm{~g} \mathrm{C} \mathrm{m}^{-2}$ and a conservative biomass-specific respiration rate of $0.01 \mathrm{~d}^{-1}$; Coma et al. 2002), which is $83 \%$ of the community respiration. Both conservative rough calculations suggest an important role of predatory anemones in the transfer of pelagic carbon to the benthic community. Hence, predator-prey interactions can be important for the carbon influx at this station.

Franco et al. (2008b) determined nematode $\delta^{13} \mathrm{C}$ and $\delta^{15} \mathrm{~N}$ values (specimens from the genera Richtersia and Sabatieria and others) at Stn $115_{\text {FINE }}$ (Fig. 4), which allows for a unique nematode-macrobenthos comparison. The nematode community (retained on a $38 \mu \mathrm{m}$ sieve) had similar isotope values to the large Nematoda (retained on a $500 \mu \mathrm{m}$ sieve) investigated here (Fig. 4). Interestingly, the $\delta^{13} \mathrm{C}$ of nematodes is closer to the $\delta^{13} \mathrm{C}$-wPOM and $\delta^{13} \mathrm{C}$-sPOM than macrobenthic taxa are. Nematodes feed on a fraction of organic matter that is different from the fraction that macrobenthic taxa feed on. Isotope tracer experiments on cores collected from Stn $115_{\mathrm{FINE}}$ have shown that uptake of ${ }^{13} \mathrm{C}$ labeled algae and Phaeocystis was insufficient to meet the metabolic demands of nematodes (Franco et al. 2008a), which indeed may indicate non-selective feeding.

The macrobenthic community at Stn $330_{\text {COARSE }}$ is typical for a mobile and permeable sediment with a dominance of Nephtys spp. and the presence of several epibenthic amphipods such as Bathyporeia spp. and Urothoe brevicornis (Van Hoey et al. 2004). Aller \& Aller (2004) found a similar community dominated by tubiculous amphipods and small polychaetes in physically disturbed and mobile sediments. They suggest that physical disturbance inhibits the build-up of a large macrobenthic community, increasing the contribution of bacterial respiration as compared to less disturbed sediments. Similarly, M. A. Franco \& J. 
Vanaverbeke (unpubl. data) found a higher contribution of bacterial respiration to the community respiration at Stn $330_{\text {COARSE }}$ than at Stn $115_{\text {FINE, }}$ suggesting that physical disturbance shapes the macrobenthic community.

In conclusion, the input to and processing of organic matter in the sediment differed between the 2 stations, which experienced comparatively similar hydrodynamic conditions. The higher silt content at the coastal Stn $115_{\text {FINE }}$ was primarily caused by a coastal high turbidity field. Sediment characteristics at the finesediment Stn $115_{\mathrm{FINE}}$ indicated a stable and less permeable sediment. The deposition of the algal bloom in spring was comparatively high and resulted in a strong vertical gradient of chl $a$. The $\delta^{13} \mathrm{C}$ and $\delta^{15} \mathrm{~N}$ values of sPOM followed those of wPOM, further indicating the high pelagic input at Stn $115_{\mathrm{FINE}}$. The high suspensionfeeding biomass suggests that an important fraction of the carbon input was biologically mediated, with contributions from both the herbivore and predatory pathways. In contrast, sediment characteristics at Stn $330_{\text {COARSE }}$ indicated a permeable and mobile sediment. Chl a penetration during and after the spring bloom was centimeters deep and showed no vertical gradient, indicating physically mediated input of algal carbon. The macrobenthic community, low in abundance, was characteristic of a physically disturbed sediment, with a dominance of mobile polychaetes and epibenthic amphipods. Overall, the fraction of algal carbon degraded in the sediment was higher at Stn $115_{\text {FINE }}$ than at Stn $330_{\text {COARSE }}$ indicating that the physical input at Stn $330_{\text {COARSE }}$ was less efficient than the biological input at Stn $115_{\mathrm{FINE}}$.

Acknowledgements. Thanks to the crews of the RV 'Belgica' and RV 'Zeeleeuw' for their skilled assistance during sampling. Thanks to R. Boogaerts for sorting the macrobenthic samples and D. Van Gansbeke for the analysis of pigment samples. Thanks to M. Fettweis for feedback on sedimentary processes on the BCS. This research was funded by the Belgian Science Policy (TROPHOS - Contract no. EV/02/25A) and the UGENT-BOF project 01GZ0705 Biodiversity and Biogeography of the Sea (BBSea) (2005-2010). The authors acknowledge the support of the MarBEF Network of Excellence 'Marine Biodiversity and Ecosystem Functioning', which is funded by the Sustainable Development, Global Change and Ecosystems Programme of the European Community's Sixth Framework Programme (contract no. GOCECT-2003-505446). This publication is contribution number MPS-09023 of MarBEF and publication number 4514 of the Netherlands Institute of Ecology (NIOO-KNAW), Yerseke.

\section{LITERATURE CITED}

Aller JY, Aller RC (2004) Physical disturbance creates bacterial dominance of benthic biological communities in tropical deltaic environments of the Gulf of Papua. Cont Shelf Res 24:2395-2416
Aller RC, Blair NE (2004) Early diagenetic remineralization of sedimentary organic $\mathrm{C}$ in the Gulf of Papua deltaic complex (Papua New Guinea): net loss of terrestrial C and diagenetic fractionation of $\mathrm{C}$ isotopes. Geochim Cosmochim Acta 68:1815-1825

Altabet MA, Francois R (1994) Sedimentary nitrogen isotopic ratio as a recorder for surface ocean nitrate utilization. Global Biogeochem Cycles 8:103-116

Anthony KRN (1997) Prey capture by the sea anemone Metridium senile (L.): effects of body size, flow regime, and upstream neighbors. Biol Bull (Woods Hole) 192: 73-86

Chiantore M, Cattaneo-Vietti R, Albertelli G, Misic C, Fabiano M (1998) Role of filtering and biodeposition by Adamussium colbecki in circulation of organic matter in Terra Nova Bay (Ross Sea, Antarctica). J Mar Syst 17: 411-424

Coma R, Ribes M, Gili JM, Zabala M (2002) Seasonality of in situ respiration rate in three temperate benthic suspension feeders. Limnol Oceanogr 47:324-331

D'Andrea AF, Aller RC, Lopez GR (2002) Organic matter flux and reactivity on a South Carolina sandflat: the impacts of porewater advection and macrobiological structures. Limnol Oceanogr 47:1056-1070

> Dauwe B, Middelburg JJ, Van Rijswijk P, Sinke J, Herman PMJ, Heip CHR (1999) Enzymatically hydrolyzable amino acids in North Sea sediments and their possible implication for sediment nutritional values. J Mar Res 57:109-134

DeNiro MJ, Epstein S (1977) Mechanism of carbon isotope fractionation associated with lipid synthesis. Science 197: 261-263

> Fettweis M, Van den Eynde D (2003) The mud deposits and the high turbidity in the Belgian-Dutch coastal zone, southern bight of the North Sea. Cont Shelf Res 23: 669-691

> Franco MA, Soetaert K, Costa MJ, Vincx M, Vanaverbeke J (2008a) Uptake of phytodetritus by meiobenthos using C13 labelled diatoms and Phaeocystis in two contrasting sediments from the North Sea. J Exp Mar Biol Ecol 362: $1-8$

> Franco MA, Soetaert K, van Oevelen D, Van Gansbeke D, Costa MJ, Vincx M, Vanaverbeke J (2008b) Density, vertical distribution and trophic responses of metazoan meiobenthos to phytoplankton deposition in contrasting sediment types. Mar Ecol Prog Ser 358:51-62

- Fréchette M, Bacher C (1998) A modelling study of optimal stocking density of mussel populations kept in experimental tanks. J Exp Mar Biol Ecol 219:241-255

Fukumori K, Oi M, Doi H, Takahashi D and others (2008) Bivalve tissue as a carbon and nitrogen isotope baseline indicator in coastal ecosystems. Estuar Coast Shelf Sci 79: $45-50$

- Hentschel BT (1998) Intraspecific variations in $\delta^{13} \mathrm{C}$ indicate ontogenetic diet changes in deposit-feeding polycheates. Ecology 79:1357-1370

> Holohan BA, Klos EG, Oviatt CA (1998) Population density, prey selection, and predator avoidance of the burrowing anemone (Ceriantheopsis americanus) in Narragansett Bay, Rhode Island. Estuaries Coasts 21:466-469

Huettel M, Rusch A (2000) Transport and degradation of phytoplankton in permeable sediment. Limnol Oceanogr 45:534-549

Huettel M, Ziebis W, Forster S (1996) Flow-induced uptake of particulate matter in permeable sediments. Limnol Oceanogr 41:309-322

> Kautsky N, Evans S (1987) Role of biodeposition by Mytilus edulis in the circulation of matter and nutrients in a Baltic 
coastal ecosystem. Mar Ecol Prog Ser 38:201-212

Lancelot C, Spitz Y, Gypens N, Ruddick K and others (2005) Modelling diatom and Phaeocystis blooms and nutrient cycles in the Southern Bight of the North Sea: the MIRO model. Mar Ecol Prog Ser 289:63-78

Laws EA, Popp BN, Bidigare RR, Kennicutt MC, Macko SA (1995) Dependence of phytoplankton carbon isotopic composition on growth rate and $\left[\mathrm{CO}_{2}\right]_{\mathrm{aq}}$ : theoretical considerations and experimental results. Geochim Cosmochim Acta 59:1131-1138

Lehmann MF, Bernasconi SM, McKenzie JA, Barbieri A, Simona M, Veronesi M (2004) Seasonal variation of the $\delta^{13} \mathrm{C}$ and $\delta^{15} \mathrm{~N}$ of particulate and dissolved carbon and nitrogen in Lake Lugano: constraints on biogeochemical cycling in a eutrophic lake. Limnol Oceanogr 49:415-429

Lorrain A, Paulet YM, Chauvaud L, Savoye N, Donval A, Saout C (2002) Differential $\delta^{13} \mathrm{C}$ and $\delta^{15} \mathrm{~N}$ signatures among scallop tissues: implications for ecology and physiology. J Exp Mar Biol Ecol 275:47-61

Megens L, van der Plicht J, de Leeuw JW (2001) Temporal variations in ${ }^{13} \mathrm{C}$ and ${ }^{14} \mathrm{C}$ concentrations in particulate organic matter from the southern North Sea. Geochim Cosmochim Acta 65:2899-2911

Minagawa M, Wada E (1984) Stepwise enrichment of ${ }^{15} \mathrm{~N}$ along food chains: further evidence and the relation between $\delta^{15} \mathrm{~N}$ and animal age. Geochim Cosmochim Acta 48:1135-1140

Nadon MO, Himmelman JH (2006) Stable isotopes in subtidal food webs: Have enriched carbon ratios in benthic consumers been misinterpreted? Limnol Oceanogr 51: $2828-2836$

> Nakatsuka T, Handa N, Wada E, Wong CS (1992) The dynamic changes of stable isotopic ratios of carbon and nitrogen in suspended and sedimented particulate organic matter during a phytoplankton bloom. J Mar Res 50:267-296

Paulet YM, Lorrain A, Richard J, Pouvreau S (2006) Experimental shift in diet $\delta^{13} \mathrm{C}$ : a potential tool for ecophysiological studies in marine bivalves. Org Geochem 37: 1359-1370

Pinheiro JC, Bates DM (2000) Mixed-effects models in S and S-PLUS. Springer, New York

Post DM (2002) Using stable isotopes to estimate trophic position: models, methods, and assumptions. Ecology 83: 703-718

Raikow DF, Hamilton SK (2001) Bivalve diets in a midwestern US stream: a stable isotope enrichment study. Limnol Oceanogr 46:514-522

Rousseau V, Leynaert A, Daoud N, Lancelot C (2002) Diatom succession, silicification and silicic acid availability in Bel- gian coastal waters (Southern North Sea). Mar Ecol Prog Ser 236:61-73

Rusch A, Forster S, Huettel M (2001) Bacteria, diatoms and detritus in an intertidal sandflat subject to advective transport across the water-sediment interface. Biogeochemistry 55:1-27

Sato T, Miyajima T, Ogawa H, Umezawa Y, Koike I (2006) Temporal variability of stable carbon and nitrogen isotopic composition of size-fractionated particulate organic matter in the hypertrophic Sumida River Estuary of Tokyo Bay, Japan. Estuar Coast Shelf Sci 68:245-258

Sebens KP, Koehl MAR (1984) Predation on zooplankton by the benthic anthozoans Alcyonium siderium (Alcyonacea) and Metridium senile (Actiniaria) in the New England subtidal. Mar Biol 81:255-271

$>$ Smaal AC, Zurburg W (1997) The uptake and release of suspended and dissolved material by oysters and mussels in Marennes-Oléron Bay. Aquat Living Resour 10:23-30

Sun MY, Aller RC, Lee C (1991) Early diagenesis of chlorophyll $a$ in Long Island Sound sediments: a measure of carbon flux and particle reworking. J Mar Res 49:379-401

Thunell RC, Sigman DM, Muller-Karger F, Astor Y, Varela R (2004) Nitrogen isotope dynamics of the Cariaco Basin, Venezuela. Global Biogeochem Cycles 18:GB3001 doi:10. 1029/2003GB002185

van der Zee C, Chou L (2005) Seasonal cycling of phosphorus in the Southern Bight of the North Sea. Biogeosciences 2: 27-42

- Van Hoey G, Degraer S, Vincx M (2004) Macrobenthic community structure of soft-bottom sediments at the Belgian Continental Shelf. Estuar Coast Shelf Sci 59:599-613

Venables WN, Ripley BD (2002) Modern applied statistics with S. Springer, New York

Waser NAD, Harrison PJ, Nielsen B, Calvert SE, Turpin DH (1998) Nitrogen isotope fractionation during the uptake and assimilation of nitrate, nitrite, ammonium, and urea by a marine diatom. Limnol Oceanogr 43:215-224

Wlodarska-Kowalczuk M, Szymelfenig M, Zajiczkowski M (2007) Dynamic sedimentary environments of an Arctic glacier-fed river estuary (Adventfjorden, Svalbard). II. Meioand macrobenthic fauna. Estuar Coast Shelf Sci 74: 274-284

Wright SW, Jeffrey SW (1997) High-resolution HPLC system for chlorophylls and caretenoids of marine phytoplankton. In: Jeffrey SW, Mantoura RFC, Wright SW (eds) Phytoplankton pigments in oceanography: guidelines to modern methods. UNESCO, Paris, p 327-341

Ysebaert T, De Neve L, Meire P (2000) The subtidal macrobenthos in the mesohaline part of the Schelde Estuary (Belgium): influenced by man? J Mar Biol Assoc UK 80: $587-597$

Submitted: December 20, 2008; Accepted: January 6, 2009 Proofs received from author(s): March 25, 2009
Editorial responsibility: Paul Snelgrove, St. John's, Canada 